\title{
DISTRIBUTION OF WHITE GRUBS IN THREE ECOLOGICAL DOMAINS OF NEPAL
}

\author{
Dipak Khanal ${ }^{1 *}$, Yubak Dhoj $\mathrm{GC}^{2}$, Marc Sporleder ${ }^{3}$ and Resham B. Thapa ${ }^{1}$
}

\begin{abstract}
A survey was conducted to study the abundance and distribution of white grubs in three districts representing different ecological domines in the country during June-July 2010. Two light traps were installed for two nights in two locations each of Makawanpur, Tanahu and Chitwan districts, and a season long light trap was installed at Mangalpur of Chitwan district from April to September 2010 for assessing scarab beetles flight activity. The 'simple matching coefficient' revealed high similarity $>70 \%$ between two sites in each of the districts, while a similarity of $29-50 \%$ was observed between sites of different districts. The Jaccard coefficient revealed the same trend. However, coefficients were much lower, above 40\% when comparing sites within a district, and below 20\% when compared sites among the districts. The dominant species in Chitwan were Anomala dimidiata Hope (24\%) followed by Maladera affinis Blanchard (23.75\%), Anomala varicolor (Gyllenhal) Rutelinae (23\%), Heteronychus lioderus Redtenbacher (14\%) and Holotrichia sp (7\%). The flight activity and species composition of scarab beetles in the three districts appeared to be different.
\end{abstract}

Key words: Abundance, distribution, dominant species, white grub

\section{INTRODUCTION}

White grubs (Coleoptera: Scarabaeidae) are the soil-living and root feeding immature stages of scarab beetles, of which both adult and larval stages are destructive in nature. The white grub family is the second largest omnipresent family, which includes over 30,000 species (Mittal, 2000). The larvae of these beetles are associated with numbers of crops and sometimes cause economic losses (GC et al., 2009). The damage caused by scarab larvae is estimated to reduce the crop yield by about 40-80\% (Prasad and Thakur, 1959; Raodeo, 1974), and in a more recent study by about 12-60\% (Pokhrel, 2004). Until recently, three main genera, i.e. Phylophaga sp., Holotricha sp. and Anomala sp. were reported to be major pests in Nepal (Joshi, 1994; Neupane, 1995). Several species of white grubs, including Phyllophaga crinita Burmeister, Phyllophaga congrua (LeConte), Phyllophaga crassissima (Blanchard), and Cyclocephala lurida (Bland), are root-feeding pests of turfgrass, forage grass, corn, small grains, sugarcane, strawberry, potato tubers, and young nursery trees (Crocker et al., 1996). The grubs feed on roots of almost all the crops, like potato, maize, wheat, barley, jowar, bajra, groundnut, sesame, sunflower, chilies, cotton, sugarcane, tobacco, brinjal, cucurbit, and lady's finger including turf, meadows, lawns and forest trees (Oya, 1995; Fujiie and Yokoyama, 1996: Arita et al., 1993; Potter et al., 1992). The larvae prefer corn, groundnut, potatoes and strawberries but dislike legumes (Matheson, 1985), sweet clover (Metcalf and Flint, 1975) and lucerne (Keller et al., 2000). Therefore, monitoring of the white grub in three agro-climatic domains Makawanpur, Tananhu and Chitwan districts of Nepal were done for their distribution and identification and effective management.

\section{OBJECTIVE}

The objective of this study was to identify the different species of white grubs and their densities present in three ecological domains represented by two locations in each of the Makawanpur, Tananhu and Chitwan districts.

\footnotetext{
${ }^{1}$ Inst. of Agri. and Ani. Sc., Rampur, Chitwan, Nepal, 2 Plant Protection Directorate, Harihar Bhawanu, International Potato Center (CIP)
} 


\section{MATERIALS AND METHODS}

White grubs and their adults were collected from two locations in each of the districts using light traps to assess their prevalence in field crops.

\section{ADULT MONITORING}

Adults monitoring was done to determine the species occurrence and relative densities during June-July, 2010. For collection of adults scarab beetles, two light traps were installed for 2 nights in two different locations of each district; Daman $\left(27^{\circ} 60^{\prime} 555 \mathrm{~N}\right.$, $85^{\circ} 09^{\prime} 095 \mathrm{E}$ and $2303 \pm 10 \mathrm{~m}$ altitude amsl) and Lamatar $\left(27^{\circ} 50^{\prime} 101 \mathrm{~N}, 85^{\circ} 06^{\prime} 859 \mathrm{E}\right.$ and $2260 \pm 6 \mathrm{~m}$ altitude amsl) of Makawanpur district representing high altitude, Ghasikuwa $\left(27^{\circ} 96^{\prime} 792 \mathrm{~N}, 84^{\circ} 41^{\prime} 011 \mathrm{E}\right.$ and $542 \pm 8 \mathrm{~m}$ altidute amsl) and Bhanu $\left(28^{\circ} 08^{\prime} 195 \mathrm{~N}, 84^{\circ} 41^{\prime} 041 \mathrm{E}\right.$ and $486 \pm 6 \mathrm{~m}$ altitude amsl) of Tanahu district representing middle altitude and Bachuli $\left(27^{\circ} 58^{\prime} 126 \mathrm{~N}, 84^{\circ} 51^{\prime} 336 \mathrm{E}\right.$ and $184 \pm 7 \mathrm{~m}$ altitude amsl) and Patiyani $\left(27^{\circ} 57^{\prime} 880 \mathrm{~N}, 84^{\circ} 35^{\prime} 040\right.$ $\mathrm{E}$ and $180 \pm 5 \mathrm{~m}$ altitude amsl) of Chitwan district representing lower altitude. During monitoring activities of scarab beetles, light trap with 18 watt CFL electric bulb was operated in farmer's field. Insects attracted to the light traps were collected into a nylon mess through a funnel trap fitted just beneath the electric light. Trapped insects were separated into scarab beetles and others; scarab beetles only were counted and preserved for taxonomical identification. Scarab beetles were kept in a vial of $15 \mathrm{~cm}$ height $\times 7 \mathrm{~cm}$ diameter size. A cotton swab with ethyl acetate moistened placed inside the vial was used as a killing agent. Collected beetles were pinned properly, stored in an insect collection box and brought to the Entomology Division (NARC) in Khumaltar and Plant Protection Directorate in Harihar Bhawan for identification based on reference insects maintained there.

\section{SEASON LONG MONITORING OF SCARAB BEETLE AT MANGALPUR, CHITWAN}

Long-season monitoring of white grub adults using light traps was conducted from 24 April to 5 September, 2010 at Mangalpur VDC of Chitwan district. The light trap was installed in farmer's field. The trap was AC-powered, had a 125 watt tungsten bulb, and was operated each alternate night over the study period. A nylon mesh was fixed for the collection of the trapped insects. Light trapped insects in the nylon mesh were collected each alternate day (i.e. in 2-days intervals), pinned in the insect collection box and then transported to Entomology Division of NARC. Identification was confirmed through Plant Protection Directorate.

Simple matching coefficient and Jaccard coefficient were used to analyze similarities between the sites and Chi-Square distance for dissimilarities of scarab beetles.

\section{RESULTS}

The highest numbers of scarab beetles were caught in Daman (32 adults), followed by Lamatar (21 adults) VDCs of Makawanpur district and the lowest numbers were caught in Bachuli (6 adults) VDC of Chitwan district. The highest numbers of beetle genera (6) were attracted in light trap I of Makawanpur and light trap II of Tanahu, while the lowest (4) were trapped in light trap II of Makawanpur and light trap I of Chitwan district. Anomala dimidiata Hope, A. varicolor (Gyllenhal) Rutellenhal, and Heteronychus lioderus Redtenbacher were the dominant species in high hills, mid-hill and terai, respectively. The beetle species and their numbers trapped in each location are presented in Table 1. A total number of 13 species were collected from the light traps in 3 districts.

The Jaccard coefficient revealed the same trend, however, coefficients were much lower, i.e. above $40 \%$ when comparing sites of the same district and between $0-20 \%$ only when sites of different districts were compared (Table 3 ). This indicated that the insect species prevailing in the study sites, especially in the different agro-ecological zones (districts) were quite variable. Relative high 'simple matching' coefficient for sites from different districts of about $40 \%$ were mainly due to the absences of white grub species in both sites; 
however, presence of the same species between sites from different agro-ecologies (districts) was limited. Nevertheless, some species appeared in all three ecological zones i.e. Mimela inscripta (Nonfried).

Table 1. Species and numbers of of white grubs trapped in three locations

\begin{tabular}{|c|c|c|c|c|c|c|}
\hline \multirow[t]{2}{*}{ Scarab beetle species } & \multicolumn{2}{|c|}{ Makawanpur } & \multicolumn{2}{|c|}{ Tanahu } & \multicolumn{2}{|c|}{ Chitwan } \\
\hline & I & II & I & II & I & II \\
\hline Anomala dimidiata Hope & 11 & 17 & & & & 2 \\
\hline Allisonotum simile (Dynastinae) & 1 & & & 2 & & \\
\hline Anomala varicolor (Gyllenhal) & & & 7 & 5 & & \\
\hline Coprius indicus (Blanchard) & 6 & 1 & & & & \\
\hline Heteronychus lioderus Redtenbacher & & & & & 2 & 3 \\
\hline Holotrichia nigricollis Brenske & & & & & 1 & 2 \\
\hline Holotrichia sp. & & & 1 & 2 & & 1 \\
\hline Lepidiota albistigma Burmeister & & & & & 2 & 1 \\
\hline Maladera affinis (Blanchard) & & & 2 & 2 & & \\
\hline Mimela inscripta (Nonfried) & 3 & & & 1 & 1 & \\
\hline Pentodon algerinum indicum Endroedi & 4 & 1 & 1 & & & \\
\hline Sophrops spp. & & & 3 & 1 & & \\
\hline Xylotrupes Gideon Linnaeus & 7 & 2 & & & & \\
\hline Dung beetle & & & & & & 21 \\
\hline Total & 32 & 21 & 14 & 13 & 6 & 30 \\
\hline
\end{tabular}

The 'simple matching' coefficient revealed relative high similarity of above $70 \%$ when comparing the two sites in each district, while similarities between sites from different districts were low, i.e. between 2950\% (Table 2).

Table 2. Simple matching coefficient for the six different sites in three locations

\begin{tabular}{|c|c|c|c|c|c|c|c|}
\hline \multirow{3}{*}{ Districts } & \multicolumn{7}{|c|}{ Proximity matrix (Simple matching measure) } \\
\hline & & \multicolumn{2}{|c|}{ Makwanpur } & \multicolumn{2}{|c|}{ Tanahu } & \multicolumn{2}{|c|}{ Chitwan } \\
\hline & & I & II & I & II & 1 & II \\
\hline \multirow[t]{2}{*}{ Makwanpur } & $\mathrm{I}$ & 1.00 & 0.86 & 0.36 & 0.43 & 0.43 & 0.29 \\
\hline & II & & 1.00 & 0.50 & 0.29 & 0.43 & 0.43 \\
\hline \multirow[t]{2}{*}{ Tanahu } & I & & & 1.00 & 0.79 & 0.36 & 0.36 \\
\hline & II & & & & 1.00 & 0.43 & 0.29 \\
\hline \multirow[t]{5}{*}{ Chitwan } & I & & & & & 1.00 & 0.71 \\
\hline & II & & & & & & 1.00 \\
\hline & $\mathrm{N}$ & $27^{\circ} 60^{\prime} 550$ & $27^{\circ} 50^{\prime} 101$ & $27^{\circ} 96^{\prime} 792$ & $28^{\circ} 08^{\prime} 195$ & $27^{\circ} 58^{\prime} 126$ & $27^{\circ} 57^{\prime} 880$ \\
\hline & $E$ & $85^{\circ} 09^{\prime} 095$ & $85^{\circ} 06^{\prime} 859$ & $84^{\circ} 41^{\prime} 011$ & $84^{\circ} 41^{\prime} 041$ & $84^{\circ} 51^{\prime} 336$ & $84^{\circ} 35^{\prime} 040$ \\
\hline & Altitude (masl) & 2303 & 2260 & 542 & 486 & 184 & 180 \\
\hline
\end{tabular}

I and II= Replication sites, $\mathrm{N}=$ North latitude, $\mathrm{E}=$ East longitude

Table 3. Jaccard coefficient for the six different sites

\begin{tabular}{ccccccc}
\hline \multirow{2}{*}{ Districts } & \multicolumn{3}{c}{ Proximity Matrix (Jaccard Measure) } \\
& Makwanpur & \multicolumn{2}{c}{ Tanahu } & \multicolumn{2}{c}{ Chitwan } \\
& I & II & I & II & I & II \\
\hline Makwanpur I & 1.00 & 0.67 & 0.10 & 0.20 & 0.11 & 0.09 \\
Makwanpur II & & 1.00 & 0.13 & 0.00 & 0.00 & 0.11 \\
Tanahu I & & & 1.00 & 0.57 & 0.00 & 0.10 \\
Tanahu II & & & & 1.00 & 0.11 & 0.09 \\
Chitwan I & & & & & 1.00 & 0.43 \\
Chitwan II & & & & & & 1.00 \\
\hline
\end{tabular}

I and II= replication site

For accounting for differences in insect species present and their difference in abundance, the Chi-square distance between all sites was calculated (Table 4). The Chisquare distance almost revealed the same results as the similarity indices (that consider presence and absence of species only but not their number). The six different 
sites observed by comparing the frequencies of white grubs showed highly significant difference between Makawanpur I and Chitwan II.

Table 4. Proximity matrix showing the Chi-square between frequencies of insects

\begin{tabular}{cccccc|c|cc}
\hline \multicolumn{9}{c}{ Proximity Matrix (Chi-square between Sets of Frequencies) } \\
\hline \multirow{2}{*}{ Districts } & \multicolumn{3}{c}{ Makwanpur } & \multicolumn{2}{c}{ Tanahu } & \multicolumn{2}{c}{ Chitwan } & $\begin{array}{c}\text { Dung } \\
\text { beetle } \\
\text { (excluded) }\end{array}$ \\
\cline { 2 - 7 } & I & II & I & II & I & II & (x) \\
\hline $\begin{array}{c}\text { Makwanpur } \\
\text { I }\end{array}$ & 0.00 & 3.41 & $6.50^{*}$ & $6.17^{*}$ & $5.69^{*}$ & $7.43^{* *}$ & $\left(5.58^{*}\right)$ \\
$\begin{array}{c}\text { Makwanpur } \\
\text { II }\end{array}$ & & 0.00 & $5.74^{*}$ & $5.83^{*}$ & $5.20^{*}$ & $6.60^{*}$ & $\left(4.63^{*}\right)$ \\
Tanahu I & & 0.00 & 2.37 & 4.47 & $6.46^{*}$ & $\left(4.57^{*}\right)$ \\
Tanahu II & & & 0.00 & $4.08^{*}$ & $6.31^{*}$ & $\left(4.39^{*}\right)$ \\
Chitwan I & & & & 0.00 & $4.21^{*}$ & $(2.11)$ \\
Chitwan II & & & & & 0.00 & \\
\hline
\end{tabular}

Numbers that are marked with asterisk indicate significant differences between the two compared sites $\left({ }^{*} P<0.05,{ }^{* *} P<0.01,{ }^{* * *} P<0.001\right)$. Numbers in parenthesis indicate Chi-square distance between Chitwan II and other sites. The Chi-square distance was also calculated by excluding the dung beetles recorded in Chitwan II.

similar distances (differences) when comparing with other sites (Table 4).

Dung beetles were observed in high number at one site of Chitwan II. Because these numbers changed considerably. The Chi-square distance when comparing these sites with others the dung beetles were removed from the analysis. Then Chitwan II showed almost

\section{SEASON LONG MONITORING OF SCARAB BEETLE AT MANGALPUR, CHITWAN}

The species Anomala dimidiata Hope were caught more or less throughout the experiment period while the highest numbers with peak activity were observed from early June to late July (Fig.1). The dominant species in Mangalpur, Chitwan were Anomala dimidiata Hope (24\%) followed by Maladera affinis (Blanchard) (23.75\%), A. varicolor (Gyllenhal) (23\%), Heteronychus lioderus Redtenbacher (14\%) Holotrichia sp. (7\%) and minor species were Sophrops sp., Chiloloba acuta Wiedemann, Mimela inscripta (Nonfried), Xylotrupes gideon Linnaeus, Lepidiota albistigma Burmeister, Pentodone algerinum Endroedi, Holotrichia nigricolis Brenske, Allisonotum simile (Dynastinae) and Coprius indicus Arrow. A. varicolor (Gyllenhal) and M. affinis (Blanchard), which showed peak activity from late April to late May, while $H$. lioderus Redtenbacher and Holotrichia sp. showed peak activity from the date of light trap installment to early May.

\section{DISCUSSIONS}

All total thirteen species of scarab beetle were collected using two light traps in each district at two spots during two nights consecutively (Annex 1). This might be due to the short study period capturing time of two nights only. However, this period is considered the peak time for adult scarab beetles activity. This study showed that Anomala dimidiata Hope and $A$. varicolor (Gyllenhal) were found

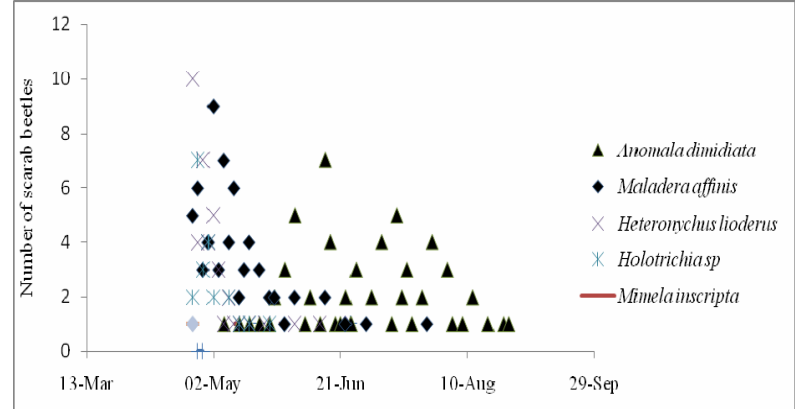

Fig.1: Number of major five scarab beetle species caught in light trap, installed at Mangalpur, Chitwan (24 April to 7 September, 2010) to be the dominant species in high-hill and mid-hill of Nepal. Similar species were found dominant by GC et.al, (2009) who mentioned that Anomala groups were cosmopolite 
species found in Gaindakot, Rampur, Gunganagar, Pang and Rising Patan of Nepal. Other species observed at the study site were Allissonotum simile (Dynastinae), Coprius indicus Arrow, Holotrichia nigricolis Brenske, Holotrichia sp., Maladera affinis (Blanchard), Mimela inscripta (Nonfried), Pentodone algerinum Endroedi, Heteronychus lioderus Redtenbacher, Sophrops spp., Xylotrupes gideon Linnaeus and Lepidiota albistigma Burmeister.

The results of regular monitoring of scarab beetles through light trap for the time of 4 months from 24 April to 7 September, 2010 at Mangalpur, Chitwan showed that Anomala dimidiata Hope appeared frequently throughout the monitoring period and the peak period was observed from early June to late July. The dominant species in Mangalpur, Chiwan, were Anomala dimidiata Hope (24\%) followed by Maladera affinis (Blanchard) (23.75\%), A. varicolor (Gyllenhal) (23\%), Heteronychus lioderus Redtenbacher (14\%), Holotrichia sp (7\%) and minor species were Sophrops spp., Chiloloba acuta Wiedemann, Mimela inscripta (Nonfried), Xylotrupes gideon Linnaeus, Lepidiota albistigma Burmeister, Pentodone algerinum Endroedi, and Holotrichia nigricolis Brenske, Allisonotum simile (Dynastinae) and Coprius indicus Arrow. The two species $A$. varicolor (Gyllenhal) and M. affinis (Blanchard) showed the peak activity from late April to late May, while $H$. lioderus Redtenbacher and Holotrichia sp. showed peak activity from the date of light trap installment to early May. Similar results were observed by GC et al. (2009), where large numbers of beetles caught at premises of IAAS were Maladera sp., Adoretus sp., Heteronychus sp., Anomala sp. and he also observed the peak period of early June to late July for A. dimidiata Hope, 2nd week of April to early May for Holotrichia spp., late April to late May for A. varicolor (Gyllenhal) and late April to late May for M. affinis (Blanchard), respectively.

\section{CONCLUSIONS}

The highest number (32 adults) of beetles was observed at Daman of Makawanpur district, and the lowest number ( 6 adults) at Bachuli. The result showed that $A$. dimidiata Hope and A. varicolor (Gyllenhal) were found to be the dominant species in high-hill and mid-hill of Nepal. Season long monitoring light trap installed at Mangalpur of Chitwan district showed that the dominant species there was $A$. dimidiata followed by Maladera affinis, $A$. varicolor, Heteronychus lioderus and Holotrichia $s p$ in order. This study attempted to explore the species present in three districts of Nepal. However, a comprehensive study covering the entire country still remains to be completed. The study reveals that several species of white grubs prevail in Nepalese agro-ecological domain requiring effective management approaches.

\section{ACKNOWLEDGMENT}

The authors are thankful to International Potato Center (CIP), Peru and National Agriculture Research and Development Fund (NARDF) for providing financial support and Nepal Agriculture Research Council (NARC) for technical support, to conduct this research.

\section{REFERENCES}

Arita, L. H., S. C. Furutani, M. T. Fukunda and T. R. Naketama, 1993. Feeding response of the China rose beetles to non-structural Carbohydrates in plant. Journal of Economic Entomology, 86:14161469.

Crocker, R. L., L. A. Rodriguez-del-Bosque, W. T. Nailon, Jr., and X. Wei, 1996. Flight periods of pyrgotids in Texas and egg production by Pyrgota undata (Diptera: Pyrgotidae), a parasite of Phyllophaga spp. (Coleoptera: Scarabaeidae). Southwest Entomology 21:317-324.

Fujiie, A. and T. Yoloyama, 1996. Improvement and use of Metarhizium anisopliae for controlling Anomala cuprea. In: Proceedings of the International Symposium on the use of Biological Control Agents under Integrated Pest Management. Food and Fertilizer Technology Centre, Republic of China Taiwan. FFTC Book series no.47, pp. 61-69. 
GC, Y. D., S. Keller, P. Nagel and L. Kafle, 2009 Abundance and diversity of Scarabaeid beetles (Coleoptera:Scarabaeidae) in different farming areas in Nepal. Formosan Entomology 29: $103-112$.

Joshi, S. L., 1994. Major Insect pests of Vegetable Crops in Nepal (in Nepali). FAO Fresh Vegetable and Vegetable Seed Production Project, Vegetable Development Division, Nepal.

Keller, S., A. I. David Henriet and C. Schweizer, 2000. Melollontha melolontha control sites in the canton Thargau. In: S. Keller (ed.) Integrated Control of Soil Pest Subgroup “Melolontha"Proceeding of the Meeting, 19-21 October 1998,IOBL, Switzerland,. IBOC/ WPRS Bulletin 23:73-78.

Matheson, M., 1985. Entomology for introductory courses: International books and Periodicals Supply Service, New Delhi India.629p.

Metcalf, G. L. and W. P. Flint, 1975. Destructive and useful insects, their habits and control. Tata McGraw-Hill Publishing Company Limited, New Delhi, India. 220p.

Mittal, I. C., 2000. Survey of Scarbaeid (Coleoptera) fauna of Himalchal Pradesh (India). Journal of Entomological Research 24:133-144.

Neupane, F. P., 1995. Review of agricultural entomology. Country profile-Agricultural entomology in Nepal. CAB International 83(12):1291-1302.

Oya, S., 1995. Control of Scarabaeid larvae in sweet potato by the entomopathogenic nematode Steinernema kushidai. In: Geraldine Grey (ed.) Biological Control in Systems of Integrated Pest Management. FFTC, Book series no. 47p.

Pokhrel, M. R., 2004. Field survey of white grubs and laboratory evaluation of Metarhizium anisopliae (Metsch.) Sorokin for its control with side effects on Bombyx mori Lin. M. Sc. Ag. Thesis (Unpublished), Tribhuvan University, Institute of Agriculture and Aninal Science, Rampur, Chitwan, Nepal. 134p.

Potter, D. A., C. G. Patterson and C. T. Redmond, 1992. Influence of turf grass species and tall fescue endophyte on feeding ecology of Japanese beetle and Southern masked chafer grubs. Journal of Economic Entomology 85:900-909.

Prasad, S. K. and C. Thakur, 1959. White grub Lachnosterna consanguinea Blanch: A new menace to sugarcane. Indian Journal of Entomology 21:184-189.

Raodeo, A. K., 1974. White grubs menace in Maharastra State. White Grubs Newsletter 1: 11-13.

Annex 1: Identified scarab beetles in the study

\begin{tabular}{|c|c|c|c|}
\hline Insect image & Scientific name & $\begin{array}{l}\text { Distribution } \\
\text { (trapped area) }\end{array}$ & Description \\
\hline & $\begin{array}{l}\text { Anomala } \\
\text { dimidiata Hope }\end{array}$ & $\begin{array}{l}\text { Makawanpur }(2303 \\
\text { masl and } 2260 \text { masl) } \\
\text { and Chitwan (180 } \\
\text { masl) }\end{array}$ & $\begin{array}{l}\text { Apple green, body shape broadly } \\
\text { oval, clypeus densely punctured } \\
\text { pygidium moderately transverse. }\end{array}$ \\
\hline & $\begin{array}{l}\text { Chiloloba acuta } \\
\text { Wiedemann }\end{array}$ & Absent & $\begin{array}{l}\text { Green rose chaffer, larvae move } \\
\text { ventrally and sometimes } \\
\text { dorsoventrally and have well } \\
\text { developed hairs on the body. }\end{array}$ \\
\hline & $\begin{array}{l}\text { Allisonotum } \\
\text { simile Arrow }\end{array}$ & $\begin{array}{l}\text { Makawanpur }(2303 \\
\text { masl) } \\
\text { Tanahu (486 masl) }\end{array}$ & $\begin{array}{l}\text { Black smooth and shinning, convex } \\
\text { and elongate-oval. Beetle is smaller } \\
\text { in size. }\end{array}$ \\
\hline & $\begin{array}{l}\text { Anomala } \\
\text { varicolor } \\
\text { (Gyllenhal) } \\
\text { Rutelinae }\end{array}$ & $\begin{array}{l}\text { Tanahu (486 } \\
\text { and } 542 \text { masl) }\end{array}$ & $\begin{array}{l}\text { The extremities of the tibia and the } \\
\text { tersi dark. The elytra are deeply and } \\
\text { finely punctuate striate with the } \\
\text { subsutural interval broad and closely } \\
\text { punctured. }\end{array}$ \\
\hline
\end{tabular}




\begin{tabular}{|c|c|c|c|}
\hline Insect image & Scientific name & $\begin{array}{l}\text { Distribution } \\
\text { (trapped area) }\end{array}$ & Description \\
\hline & $\begin{array}{l}\text { Maladera affinis } \\
\text { (Blanchard) }\end{array}$ & $\begin{array}{l}\text { Tanahu (486 } \\
\text { and } 542 \text { masl })\end{array}$ & $\begin{array}{l}\text { Common species of sandy soil, typical } \\
\text { segment on lateral part of larval } \\
\text { head, red color smaller in size, } \\
\text { closed pygidium with the wings. }\end{array}$ \\
\hline & $\begin{array}{l}\text { Heteronychus } \\
\text { lioderes } \\
\text { Redtenbacher }\end{array}$ & $\begin{array}{l}\text { Chitwan (184 masl } \\
\text { and } \\
180 \text { masl })\end{array}$ & $\begin{array}{l}\text { Black above, deep reddish brown } \\
\text { beneath and very smooth and shining } \\
\text { elongate-oval in shape and not very } \\
\text { convex, shinning scutellum }\end{array}$ \\
\hline & Holotrichia sp. & $\begin{array}{l}\text { Tanahu (486 masl } \\
\text { and } 542 \text { masl) }\end{array}$ & $\begin{array}{l}\text { Raster with irregular setae or with } \\
\text { two longitudinal rows of setae. }\end{array}$ \\
\hline & $\begin{array}{l}\text { Holotrichia } \\
\text { nigricollis } \\
\text { Brenske }\end{array}$ & $\begin{array}{l}\text { Chitwan (184 masl } \\
\text { and } 180 \text { masl) }\end{array}$ & $\begin{array}{l}\text { Robust, oval and brownish and } \\
\text { resemble June beetle (though most } \\
\text { are smaller) }\end{array}$ \\
\hline & $\begin{array}{l}\text { Xylotrupes } \\
\text { gideon Linnaeus }\end{array}$ & $\begin{array}{l}\text { Makawanpur ( } 2303 \\
\text { masl \&and2260 } \\
\text { masl) }\end{array}$ & $\begin{array}{l}\text { Black to dark brown beetles, chiefly } \\
\text { nocturnal, the male is a shiny black } \\
\text { with forked horns on head, female is } \\
\text { a matt black and lacks the horns. }\end{array}$ \\
\hline & Sophrops sp. & $\begin{array}{l}\text { Tanahu (486 masl } \\
\text { and } 542 \text { masl) }\end{array}$ & $\begin{array}{l}\text { Brownish, robust and oval. Beetles } \\
\text { feeds on plant foliage and larvae } \\
\text { damage the roots of crops. }\end{array}$ \\
\hline & $\begin{array}{l}\text { Lepidiota } \\
\text { albistigma } \\
\text { Burmeister }\end{array}$ & $\begin{array}{l}\text { Chitwan (184 masl \& } \\
180 \text { masl) }\end{array}$ & $\begin{array}{l}\text { Brown in color, robust and oval } \\
\text { beetles that feeds on the flowers and } \\
\text { foliage of plants, larvae are white do } \\
\text { serious damage to roots.. }\end{array}$ \\
\hline & $\begin{array}{l}\text { Pentodon } \\
\text { algerinum } \\
\text { indicum Endroedi }\end{array}$ & $\begin{array}{l}\text { Makawanpur ( } 2303 \\
\text { masl and } 2260 \text { masl) } \\
\text { and Tanahu (486 } \\
\text { masl) }\end{array}$ & $\begin{array}{l}\text { Dorsal surface of body is rounded and } \\
\text { convex, male with horn on head or } \\
\text { pronotum, female lack horn }\end{array}$ \\
\hline & $\begin{array}{l}\text { Mimela inscripta } \\
\text { (Nonfried) }\end{array}$ & $\begin{array}{l}\text { Makawanpur ( } 2303 \\
\text { masl, Tanahu ( } 542 \\
\text { masl) chitwan (184 } \\
\text { masl) }\end{array}$ & $\begin{array}{l}\text { Beetles brightly colored, commonly } \\
\text { yellowish color both adults and grubs } \\
\text { are destructive, }\end{array}$ \\
\hline & $\begin{array}{l}\text { Coprius indicus } \\
\text { Arrow }\end{array}$ & $\begin{array}{l}\text { Makawanpur (2303 } \\
\text { masl and } 2260 \text { masl) }\end{array}$ & $\begin{array}{l}\text { Black, body compact, convex or a } \\
\text { little depressed, abdomen very short, } \\
\text { femora very thick, the elytra are very } \\
\text { strongly sulcate. }\end{array}$ \\
\hline
\end{tabular}

